\title{
Ohmic heating for the dairy industry: a potential technology to develop probiotic dairy foods in association with modifications of whey protein structure
} Ricardo Nuno Pereira ${ }^{1}$, José António Teixeira ${ }^{1}$, António Augusto Vicente $^{1}$, Leandro Pereira Cappato ${ }^{2}$, Marcus Vinicius da Silva Ferreira $^{2}$, Ramon da Silva Rocha ${ }^{3}$ and Adriano Gomes da Cruz ${ }^{3}$

\begin{abstract}
The use of whey in dairy probiotics is a topic of great interest to the scientific community and the food industries. However, few studies address the effect of ohmic heating $(\mathrm{OH})$ on cell metabolism and growth parameters of probiotic microorganisms. Despite of this, $\mathrm{OH}$ under sub-lethal conditions presents promising results regarding the enhancement of growth rate and bacteriocin activity, leading to considerable improvements in the fermentation process. Thus, this review highlights the main findings and advances on the effect of $\mathrm{OH}$ on probiotic metabolism, while addressing the modification of whey protein structure as potential carrier of probiotic entities, aiming at stimulating interest and encouraging the development of functional products using $\mathrm{OH}$.

\footnotetext{
${ }^{1}$ CEB-Centre of Biological Engineering, University of Minho, Braga, Portugal

${ }^{2}$ University Federal Rural do Rio de Janeiro, Instituto de Tecnologia, Seropédica, Brazil

${ }^{3}$ Instituto Federal de Educação, Ciência e Tecnologia (IFRJ),

Departamento de Alimentos, Rio de Janeiro, Brazil
}

Addresses
\end{abstract}

Corresponding authors: Pereira, Ricardo Nuno (rpereira@deb.uminho. pt), da Cruz, Adriano Gomes (adriano.cruz@ifrj.edu.br)

\section{Current Opinion in Food Science 2018, 22:95-101 \\ This review comes from a themed issue on Innovations in food science}

Edited by Adriano Cruz

https://doi.org/10.1016/j.cofs.2018.01.014

2214-7993/@ 2018 Elsevier Ltd. All rights reserved.

\section{Introduction}

Ohmic heating $(\mathrm{OH})$ is an outstanding example of a successful emergent technology in food processing. From the beginning of the $\mathrm{XX}$ century until now $\mathrm{OH}$ has survived by taking advantage of technological evolution and gathering fundamental and applied knowledge during decades. In fact, $\mathrm{OH}$ together with novel technologies such as pulsed electric fields and high-pressure processing is in the frontline of the 'emerging high-potential technologies for tomorrow' [1]. OH is based on the simple principle that the passage of electricity through a semiconductive material will allow generation of internal heat (Joule effect). Knowing that the great majority of foodstuffs composition is rich in water, salts and organic acids, application of $\mathrm{OH}$ is straightforward.

The very first application of OH occurred in 1920 through electric pasteurization of milk that became known as 'electro-pure process of treating milk' [2]. Coincidently, or not, $\mathrm{OH}$ is now being strongly associated with many aspects of dairy processing, which include safety, quality and development of novel and healthy dairy products $\left[3^{\bullet}, 4,5\right]$ that can met the demands of a new and more active consumer.

This 'new' consumer behavior is actually shifting the paradigm of food processing that is now much more focused in developing new functional and healthier foods products. One outstanding example is the use of probiotics in dairy products that is increasingly being expanded in food industry $\left[6^{\bullet \bullet}, 7^{\bullet}\right]$. OH has been bringing new insights toward important structural and functional aspects of important macromolecules and biological entities of food products. This review provides a comprehensive summary about the potential use of $\mathrm{OH}$ in the development of probiotic dairy products based on the latest advances of the effects of this technology in biomacromolecules and dairy ingredients.

\section{Probiotic dairy foods}

Probiotics are defined as 'live microorganisms which when administered in adequate amounts confer a health benefit on the host' [8]. Recent studies show that the intake of probiotic products promotes several health benefits, as they help to maintain a good balance of the intestinal flora, as well as, increase the resistance against the invasion of pathogens [9,10]. The Lactobacillus and Bifidobacterium are the most common probiotic genera; from the Lactobacillus species the strains more commonly used are L. acidophilus, L. crispatus, L. amylovarus, L. gallinarum, L. gasseri, L. john-sonii, L. helveticus, L. delbrueckii subsp. bulgaricus, L. sali-varius subsp. salivarius, L. casei, L. paracasei subsp. paracasei, L. paracasei subsp. tolerans, 
L. plantarum, L. rhamnosus, L. fermentum, L. reuteri; while from Bifidobacterium spp. are the B. bifidum, B. longum, $B$. infanti, B. breve, B. adolescentis, B. animalis $\left[6^{\bullet \bullet}, 11\right]$.

Dairy food products such as yogurts, dairy based drinks and fermented milks are among the top probiotic foods consumed in the world. However, food must contain an adequate number of probiotics (i.e. $10^{8}$ to $10^{9}$ cells per gram of products) when consumed to have a beneficial health effect $[12,13]$. In addition, probiotics must be able withstand the harsh environmental conditions of the human gastrointestinal tract. Thus, one of the major challenges in the industry is to maintain these characteristics, because several factors during processing and storage affect the viability of probiotics.

The use of new technologies in food processing, such as $\mathrm{OH}$ has been prominent in the development of new products, and is often reported as a promising technology for the dairy industry $\left[14^{\circ}\right]$. However, information about the non-thermal effects of $\mathrm{OH}$ on the development of fermented dairy products, as well as, the effects on the metabolic activity of probiotics and the viability of the crops is still scarce, thus being a promising area for studies for future research in the dairy sector.

$\mathrm{OH}$ is being triggering research and discussion about the effects of electrical variables (such as frequency and electric fields) on biological cells and bio-macromolecules (i.e. proteins). Studies about effects of $\mathrm{OH}$ on microorganisms (either vegetative cells or spores) and enzymes have been thoroughly reviewed $\left[15^{\circ}, 16,17^{\circ}\right]$. Overall, it is unanimous that together with a promise of a direct, volumetric and fast heating, which per se bring significant changes on quality and functional aspects of proteinaceous dairy products, $\mathrm{OH}$ brings also possibility of modulate activation and inactivation of species of biological origin - i.e. microorganism and enzymes.

Fermentation of dairy products with probiotic microorganisms often involves production of enzymes. Likewise as case of microorganisms, it is generally recognized that $\mathrm{OH}$ can accelerate inactivation of certain food enzymes, especially at high temperatures. This mechanism of inactivation under alternating electric fields is not clear but is particularly evident in enzymes containing metallic prosthetic groups, such as lipoxygenase and polyphenoloxidase [18]. Equally interesting has been some latest findings about the effects of controlling frequency and electric field intensity on pectin methylesterase activity, for example. It was evidenced that treatments at temperatures ranging from $65^{\circ} \mathrm{C}$ to $90^{\circ} \mathrm{C}$, using low frequencies $(<60 \mathrm{~Hz})$ and high electric fields intensity $(>10 \mathrm{~V} /$ $\mathrm{cm})$ may enhance enzyme inactivation, while these additional effects are considered to be negligible at the opposite conditions (i.e. high electric frequency and low electric field) $[19,20]$. Latter authors also pointed out that depending on the treatment temperature, enzyme activation can also happen under $\mathrm{OH}$ eventually due to changes in electrophoretic motion and better interaction between enzymes and substrate. These novel insights turn it clear that $\mathrm{OH}$ operational variables can be used to tune enzymatic activity, which can bring a crucial advantage over several food biotechnological processes, such as fermentation and enzymatic hydrolysis.

Several authors have already evidenced enhanced inactivation of microorganisms when compared with conventional pasteurization protocols [21-25]. This additional inactivation can be a result of thermal permeabilization of cell membrane due to Joule heating effect (internal heat), resulting in the reduction of the thermal resistance (lower D values). This effect allowed to perform treatments with lower thermal intensity without affecting food safety (same $\mathrm{F}_{0}$ values) $\left[15^{\circ}\right]$. But electro-permeabilization of cell membranes - commonly known as electroporation - should not be overlooked once enhanced inactivation under moderate electric fields (MEF) it is also reported to occur at sub-lethal temperatures $[4,26]$.

In sub-lethal conditions, the electric field can promote an increase in cellular permeability and the diffusion of ions and molecules through the cell membrane, resulting in a better absorption of nutrients and, consequently, a faster cellular growth $\left[27^{\circ}\right]$. Thus, at sub-lethal conditions, $\mathrm{OH}$ can affect the metabolic processes, being an interesting alternative in biotechnological processes. Despite the few studies relating the effect of the electric field on the metabolism of probiotics in fermentative processes, the published results demonstrate promising prospects for the development of novel probiotic products through $\mathrm{OH}$.

Recent research reports that the effect of pulsed electric field $(\mathrm{PEF})$ on biotechnological processes results in improvements in kinetic parameters of growth and cellular metabolism of probiotics [28-31]. However, in relation to $\mathrm{OH}$, few studies have been found in the literature. Cho, Yousef [32] reported for the first time an activation effect on metabolic response Lactobacillus acidophilus OSU 133, an important probiotic microorganism, under ohmic heating fermentation applying MEF. Table 1 shows the results of the MEF effect under different process conditions (electric field and frequencies) on the kinetic parameters of growth and bacteriocin activity of Lactobacillus acidophilus OSU 133.

The results presented in Table 1 show that bacteriocin activity and growth parameters during the stages of growth (lag, exponential or stationary) are affected by the electric field strength and of the frequency of MEF treatment applied during fermentation. MEF applied in the initial stages resulted in increased bacteriocin activity, due to the stress caused by the electric field [33]. According to Serrazanetti, Guerzoni [36], stresses in the 
Table 1

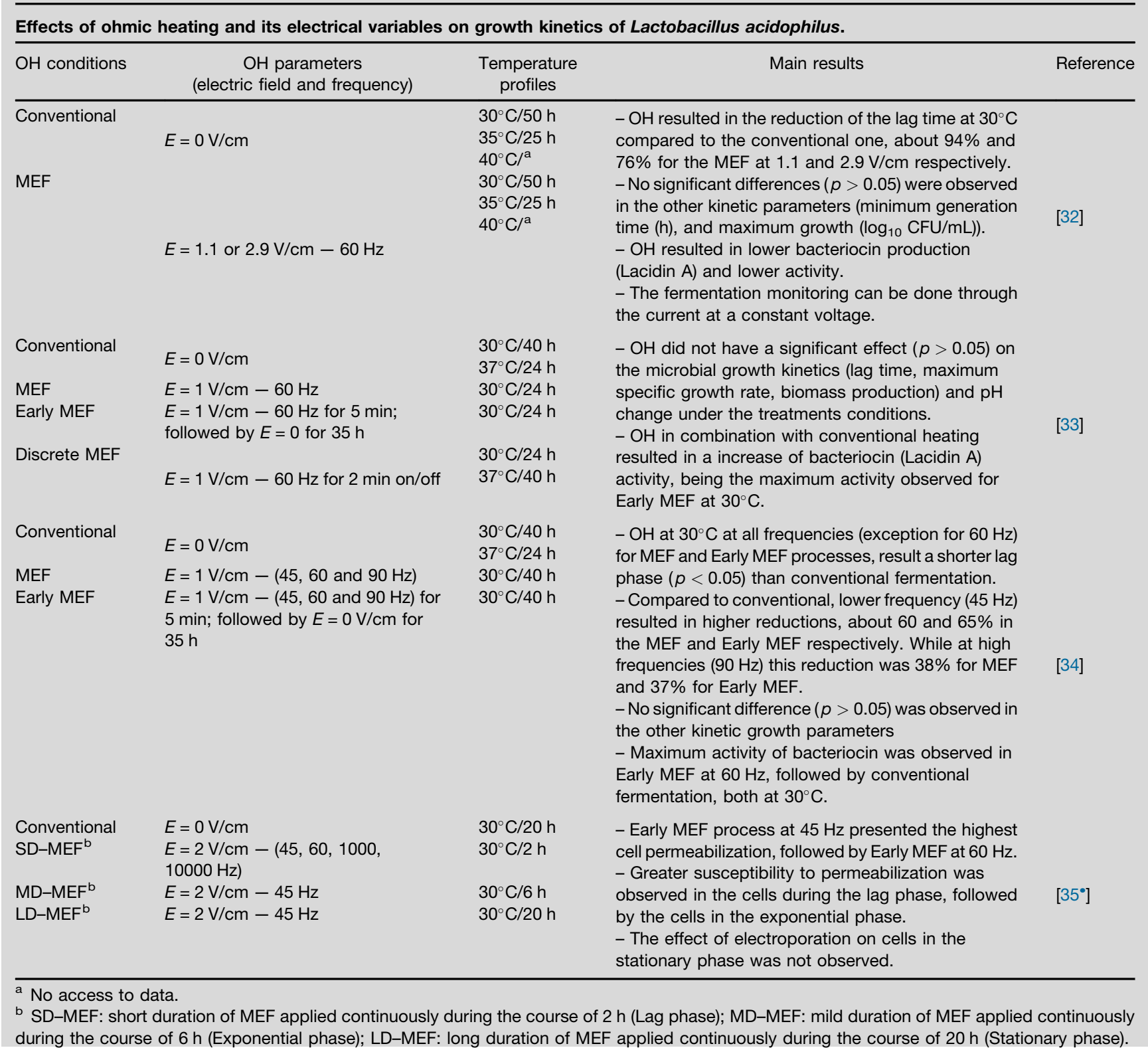

microorganism can affect metabolic processes, resulting in improvements in bioprocesses and in bioproducts.

In relation to growth parameters, the MEF applied at low frequencies $(45 \mathrm{~Hz})$ and in the initial stages resulted in the reduction of lag phase time, due to the temporary increase in cellular permeability. According to the authors, the application of electric fields may have promoted physical disturbances on cell walls helping to dislodge adhered polar antimicrobials or other molecules, thus improving absorption of nutrients during lag phase of fermentation. Temporary permeability has been proven by Loghavi, Sastry $\left[35^{\circ}\right]$ using dye staining techniques in the cells, where intact and permeabilized cells could be identified through microscopic observations.
Thus, $\mathrm{OH}$ applied and its MEF may be potentially useful in biotechnological processes, being an alternative technology in the development of fermented probiotic products. However, studies involving other probiotic strains under different parameters (electric field, frequency) should be performed, aiming at the development and optimization of the process conditions. Furthermore, the effect of $\mathrm{OH}$ on the viability and metabolic activity of probiotics are important characteristics to be evaluated, as well as studies in food matrices instead of culture media, bringing a more realistic scenario.

The metabolism and viability of probiotics are affected by different factors, such as physical-chemical characteristics of foods (such as $\mathrm{pH}$, titratable acidity), process 
parameters (temperature profiles, cooling rate, storage environment). Thus, the understanding of the effect of $\mathrm{OH}$ on the properties of dairy products, as in the conformational structure, aggregation, unfolding and denaturation of whey proteins, bioactive compounds (like bioactive peptides), fatty acids profiles and in physical properties (e.g. rheological parameters), presents as one of the great challenges for the elaboration of probiotic dairy products $\left[37,38^{\bullet}, 39\right]$. However, no information was found in this search field.

\section{Whey protein}

The use of whey, a residue of the cheese industry, shows great interest in the elaboration of functional beverages in recent years. Besides that, whey ingredients despite their recognized biological value (e.g. anti-tumoral activity, essential amino acids and immune system modulation $\left[40^{\bullet \bullet}\right]$, and technological properties (e.g. water holding capacity and gelation and emulsifying abilities) [41], they can also improve probiotic viability, rheological and sensorial characteristics of probiotic dairy products, even can also have positive effects on modulation of gut microbiota [42].

In opposition to casein fraction, whey proteins are very susceptible to thermal denaturation under pasteurization conditions. Whey proteins, for example can have positive effects on the viability of probiotics strains during processing and refrigerated storage, due the higher buffering capacity that delays the post-acidification during storage. In addition, the heat treatment may lead to the release of sulfur amino acids resulting in the reduction of the redox potential aiding in the fermentation process and in the survival of the probiotic $\left[7^{\bullet}, 43\right]$.

In reason of this, during the last few years, the effects of $\mathrm{OH}$ on whey proteins have been comprehensively investigated (see Table 2). Whey protein nano and microstructures, as well as gel-systems can be tailored with application of $\mathrm{OH}$ using different thermal loads and varying electric field intensities [44]. The presence of MEF seems to disturb the conventional pathways of protein denaturation aggregation by changing not only the size but also the morphologies of produced aggregates [38 $8^{\circ}$. This has shown to be mostly relevant in concentrated protein systems, where viscoelastic behavior of protein solutions is changed under the influence of electric fields [45]. By controlling physical-chemical environment (i.e. $\mathrm{pH}$, ionic strength, type of protein, protein concentration and electrical conductivity), in combination with certain $\mathrm{OH}$ operational conditions (i.e. electrical field intensity, temperature and time of treatment) it is possible to design protein gel networks for incorporation of functional compounds or nutrients [46]. OH can be used as pre-treatment tool to 'functionalize' globular whey proteins, for development of hydrogels or cold gel-like emulsions $[47,48]$. Latest reviews about the state-of-art of $\mathrm{OH}$ highlight the importance of evaluating the effects of this technology on allergenicity aspects (such as allergy sensitizing or eliciting potential) of food proteins $\left[3^{\circ}, 15^{\circ}\right]$. Whey proteins are considered one the major cow's milk

\begin{tabular}{|c|c|c|c|c|}
\hline \multicolumn{5}{|c|}{ Effects of ohmic heating and its electrical variables on denaturation and gelation of whey proteins. } \\
\hline Whey proteins & $\begin{array}{l}\mathrm{OH} \text { parameters (electric } \\
\text { field and frequency) }\end{array}$ & Heating conditions & Main results over conventional heating & Reference \\
\hline$\beta$-Lactoglobulin A & $4-8 \mathrm{~V} / \mathrm{cm}$ at $25 \mathrm{kHz}$ & $0.5 \mathrm{~min}$ at $85^{\circ} \mathrm{C}$ & $\begin{array}{l}\text { - Higher contents of native protein } \\
\text { detected by RP-HPLC }\end{array}$ & [45] \\
\hline$\beta$-Lactoglobulin B & $4-8 \mathrm{~V} / \mathrm{cm}$ at $25 \mathrm{kHz}$ & $0.5 \mathrm{~min}$ at $85^{\circ} \mathrm{C}$ & - No significant differences & {$[45]$} \\
\hline$\alpha$-Lactalbumin & $4-8 \mathrm{~V} / \mathrm{cm}$ at $25 \mathrm{kHz}$ & $0.5 \mathrm{~min}$ at $85^{\circ} \mathrm{C}$ & $\begin{array}{l}\text { - Higher contents of native protein } \\
\text { detected by RP-HPLC }\end{array}$ & [45] \\
\hline \multirow[t]{4}{*}{ Whey protein isolate } & $4-8 \mathrm{~V} / \mathrm{cm}$ at $25 \mathrm{kHz}$ & $30 \mathrm{mn}$ at $85^{\circ} \mathrm{C}$ & $\begin{array}{l}\text { - Gel with weaker viscoelastic structure } \\
\text { (decreases in both } \mathrm{G}^{\prime} \text { and } \mathrm{G}^{\prime \prime} \text { ) } \\
\text { - Progel state }\end{array}$ & [45] \\
\hline & $4-8 \mathrm{~V} / \mathrm{cm}$ at $50 \mathrm{~Hz}$ & $30 \mathrm{~s}$ to $30 \mathrm{~min} / 75$ to $90^{\circ} \mathrm{C}$ & $\begin{array}{l}\text { - Less protein denaturation particularly at } \\
\text { fast come-up times } \\
\text { - > } 30 \% \text { of soluble protein } \\
\text { - Denaturation kinetically traduced by } \\
\text { lower values of reaction order }(n) \text { and rate } \\
\text { constant }(k)\end{array}$ & {$[44]$} \\
\hline & $6-12 \mathrm{~V} / \mathrm{cm}$ at $25 \mathrm{kHz}$ & $5 \mathrm{~min}$ at $90^{\circ} \mathrm{C}$ & $\begin{array}{l}\text { - Protein networks characterized by the } \\
\text { presence of small fibrils } \\
\text { - Ability to reduce protein aggregation } \\
\text { levels }\end{array}$ & {$\left[38^{\circ}\right]$} \\
\hline & $10 \mathrm{~V} / \mathrm{cm}$ at $25 \mathrm{kHz}$ & $10 \mathrm{~min}$ at $90^{\circ} \mathrm{C}$ & $\begin{array}{l}\text { - Protein hydrogels with ability to } \\
\text { incorporate higher amounts of } \mathrm{Fe}^{2+} \\
\text { through a cold gelation process }\end{array}$ & {$[48]$} \\
\hline Lactoferrin & $6-20 \mathrm{~V} / \mathrm{cm}$ at $25 \mathrm{kHz}$ & $30 \mathrm{~min}$ at $90^{\circ} \mathrm{C}$ & $\begin{array}{l}\text { - Development of cold gel-like emulsions } \\
\text { with distinct gel structure }\end{array}$ & {$[47]$} \\
\hline
\end{tabular}


allergens [49]. OH either by reducing thermal load, changing whey protein aggregation pathways or altering interactions with other molecules (e.g. Maillard reactions), may be influencing allergenicity responses of these proteins, and this needs to be addressed.

Besides the effects on milk characteristics, the addition of fruit juices and pulps, a technique widely used for the elaboration of whey beverages, can affect the viability and metabolic mechanisms of probiotic strains, due to the modification of the intrinsic characteristics, such as acidity and the presence of antimicrobials $\left[7^{\circ}\right]$. Another important factor in the elaboration of probiotic products by $\mathrm{OH}$ is due to corrosion of electrodes, which may result in the migration of metal ions to the food and may adversely affect the microbial metabolism. Thus, corrosion is a major concern in the design and development of biotechnological processes in $\mathrm{OH}$. The use of inert electrodes, such as stainless steel and titanium, can prevent such a problem [50].

\section{Perspectives}

Studies involving the use of $\mathrm{OH}$ under sub-lethal conditions in growth rates and bacteriocin activity are scarce, however previous results demonstrate beneficial effects on fermentation, suggesting the need of determining the best $\mathrm{OH}$ parameters. Future studies should be performed to observe the respective effects on the metabolism of different probiotics and their viability, aiming to assist in the development of probiotic dairy products by this emerging technology.

Recent findings also point out that whey protein networks can be tailored by $\mathrm{OH}$ treatments and encompass an interesting synergetic potential to be used as a matrix for the incorporation of probiotic entities. Whey systems, with all biological and nutritional benefits associated with it, can be designed as vehicles to transport, protect and deliver probiotic during gastrointestinal digestion. Nevertheless, more fundamental knowledge is still required to understand interactions between electric fields and whey protein structures

In this sense, $\mathrm{OH}$ can open news perspectives and strategies for development of fermented probiotic products that are worthy of further research. Although, some questions arises: can electric field be used to control or tune biological responses? What are the best combinations of electric field and frequency to be applied? Are the metabolism of different probiotics affected in the same way by the electric field and what is the effect on the viability of probiotics in the products? In fact, the interaction between alternating electric fields and microorganism is far from being understood.

\section{Conflict of interest}

None declared.

\section{Acknowledgements}

This work was supported by the Portuguese Foundation for Science and Technology (FCT) under the scope of the strategic funding of UID/BIO/ 04469/2013 unit and COMPETE 2020 (POCI-01-0145-FEDER-006684) and by BioTecNorte operation (NORTE-01-0145-FEDER-000004) funded by the European Regional Development Fund under the scope of Norte2020 - Programa Operacional Regional do Norte. Pedro Santos is recipient of a fellowship supported by a doctoral advanced training (call NORTE-69-2015-15), funded by the European Social Fund under the scope of Norte2020 - Programa Operacional Regional do Norte. Ricardo Pereira is recipient of a fellowship supported by FCT (SFRH/BPD/81887/ 2011).

\section{References and recommended reading}

Papers of particular interest, published within the period of review, have been highlighted as:

- of special interest

.. of outstanding interest

1. De Vries H, Mikolajczak M, Salmon JM, Abecassis J, Chaunier L, Guessasma S, Trystram G: Small-scale food process engineering - challenges and perspectives. Innov Food Sci Emerg Technol 2017 http://dx.doi.org/10.1016/j. ifset.2017.09.009.

2. Anderson AK, Finkelstein R: A study of the electro-pure process of treating milk. J Dairy Sci 1919, 2:374-406.

3. Cappato LP, Ferreira MVS, Guimaraes JT, Portela JB, Costa ALR,

- Freitas MQ, Cunha RL, Oliveira CAF, Mercali GD, Marzack LDF, Cruz AG: Ohmic heating in dairy processing: relevant aspects for safety and quality. Trends Food Sci Technol 2017, 62: 104-112.

A very interesting review article with recent advances in the application of Ohmic Heating in dairy products

4. Kim SS, Jo Y, Kang DH: Combined inhibitory effect of milk fat and lactose for inactivation of foodborne pathogens by ohmic heating. LWT - Food Sci Technol 2017, 86:159-165.

5. Roux S, Courel M, Birlouez-Aragon I, Municino F, Massa M, Pain JP: Comparative thermal impact of two UHT technologies, continuous ohmic heating and direct steam injection, on the nutritional properties of liquid infant formula. $J$ Food Eng 2016, 179:36-43.

6. Kandylis P, Pissaridi K, Bekatorou A, Kanellaki M, Koutinas AA: -D Dairy and non-dairy probiotic beverages. Curr Opin Food Sci 2016, 7:58-63.

Very important review article with topics of the recent advances in the field of probiotic beverages both from dairy and non-dairy origin.

7. Shori AB: Influence of food matrix on the viability of probiotic - bacteria: a review based on dairy and non-dairy beverages. Food Biosci 2016, 13:1-8.

This short-review provides an overview of the application of probiotics in dairy and non-dairy based beverages and their viability during refrigerated storage.

8. FAO/WHO: Health and Nutritional Properties of Probiotics in Food including Powder Milk with Live Lactic Acid Bacteria. Cordoba, Argentina: Food and Agriculture Organization of the United Nations and World Health Organization Expert Consultation Report; 2001.

9. Cruz AG, Buriti FC, Souza CH, Faria JA, Saad SM: Probiotic cheese: health benefits, technological and stability aspects. Trends Food Sci Technol 2009, 20:344-354.

10. Zoumpopoulou G, Pot B, Tsakalidou E, Papadimitriou K: Dairy probiotics: beyond the role of promoting gut and immune health. Int Dairy J 2017, 67:46-60.

11. Fijan S: Microorganisms with claimed probiotic properties: an overview of recent literature. Int J Env Res Pub He 2014, 11:4745-4767.

12. Jayamanne VS, Adams MR: Determination of survival, identity and stress resistance of probiotic bifidobacteria in bioyoghurts. Lett Appl Microbiol 2006, 42:189-194. 
13. Lourens-Hattingh A, Viljoen BC: Growth and survival of a probiotic yeast in dairy products. Food Res Int 2001, 34 791-796.

14. Jermann C, Koutchma T, Margas E, Leadley C, Ros-Polski V:

- Mapping trends in novel and emerging food processing technologies around the world. Innov Food Sci Emerg Technol $2015,31: 14-27$.

This article discusses new technologies and their applications in the world through a study conducted with a group composed of professionals from food professionals from industry, academia and government in North America and Europe. The article is a good source for research on trends in the use of emerging technologies.

15. Jaeger H, Roth A, Toepfl S, Holzhauser T, Engel KH, Knorr D,

- Vogel RF, Bandick N, Kulling S, Heinz V, Steinberg P: Opinion on the use of ohmic heating for the treatment of foods. Trends Food Sci Technol 2016, 55:84-97.

This review summarises the main aspects regarding the use of ohmic heating in food and the main gaps exist.

16. Knirsch MC, Santos C, Vicente AA: Ohmic heating - a review. Trends Food Sci Technol 2010, 21:436-441.

17. Vicente AA, Pereira RN, Penna TCV, Knirsch M: Electricity effects

-• on microorganisms and enzymes. Ohmic Heating in Food Processing. CRC Press; 2014:93-104.

Interesting chapter discussing the effects that electricity promotes in microorganism and enzymes, showing the importance of $\mathrm{OH}$ and the need for more studies.

18. Castro I, Macedo B, Teixeira JA, Vicente AA: The effect of electric field on important food-processing enzymes: comparison of inactivation kinetics under conventional and ohmic heating. $J$ Food Sci 2004, 69:C696-C701.

19. Samaranayake CP, Sastry SK: Effects of controlled-frequency moderate electric fields on pectin methylesterase and polygalacturonase activities in tomato homogenate. Food Chem 2016, 199:265-272.

20. Samaranayake CP, Sastry SK: Effect of moderate electric fields on inactivation kinetics of pectin methylesterase in tomatoes: the roles of electric field strength and temperature. J Food Eng 2016, 186:17-26.

21. Baysal AH, Icier F: Inactivation kinetics of Alicyclobacillus acidoterrestris spores in orange juice by ohmic heating: effects of voltage gradient and temperature on inactivation. $J$ Food Prot 2010, 73:299-304.

22. Palaniappan S, Sastry SK, Richter ER: Effects of electroconductive heat treatment and electrical pretreatment on thermal death kinetics of selected microorganisms. Biotechnol Bioeng 1992, 39:225-232.

23. Pereira R, Martins J, Mateus C, Teixeira JA, Vicente AA: Death kinetics of Escherichia coli in goat milk and Bacillus licheniformis in cloudberry jam treated by ohmic heating. Chem Pap 2007, 61:121-126.

24. Park IK, Kang DH: Effect of electropermeabilization by ohmic heating for inactivation of Escherichia coli 0157:H7, Salmonella enterica serovar Typhimurium, and Listeria monocytogenes in buffered peptone water and apple juice. Appl Environ Microbiol 2013, 79:7122-7129.

25. Lee SY, Sagong HG, Ryu S, Kang DH: Effect of continuous ohmic heating to inactivate Escherichia coli 0157:H7, Salmonella Typhimurium and Listeria monocytogenes in orange juice and tomato juice. J Appl Microbiol 2012, 112 723-731.

26. Machado LF, Pereira RN, Martins RC, Teixeira JA, Vicente AA: Moderate electric fields can inactivate Escherichia coli at room temperature. J Food Eng 2010, 96:520-527.

27. Mota MJ, Lopes RP, Koubaa M, Roohinejad S, Barba FJ,

- Delgadillo I, Saraiva JÁ: Fermentation at non-conventional conditions in food- and bio-sciences by the application of advanced processing technologies. Crit Rev Biotechnol 2017, 38:122-140.

The paper reports the use of unconventional technologies in biotechnological processes and their main challenges. With the research, the authors intend to discuss the main findings in order to stimulate interest in this field.
28. Najim N, Aryana KJ: A mild pulsed electric field condition that improves acid tolerance, growth, and protease activity of Lactobacillus acidophilus LA-K and Lactobacillus delbrueckii subspecies bulgaricus LB-12. J Dairy Sci 2013, 96:3424-3434.

29. Cueva OA: Pulsed electric field influences on acid tolerance, bile tolerance, protease activity and growth characteristics of Lactobacillus acidophilus LA-K. J Microb Bioch Technol 2009, 4:137-140.

30. Ewe JA, Wan-Abdullah WN, Alias AK, Liong MT: Enhanced growth of lactobacilli and bioconversion of isoflavones in biotin-supplemented soymilk by electroporation. Int J Food Sci Nutr 2012, 63:580-596.

31. Yeo SK, Ong JS, Liong MT: Effect of electroporation on bioconversion of isoflavones and probiotic properties of parents and subsequent passages of Bifidobacterium longum. Appl Biochem Biotechnol 2014, 174:1496-1509.

32. Cho HY, Yousef AE, Sastry SK: Growth kinetics of Lactobacillus acidophilus under ohmic heating. Biotechnol Bioeng 1996, 49:334-340.

33. Loghavi L, Sastry SK, Yousef AE: Effect of moderate electric field on the metabolic activity and growth kinetics of Lactobacillus acidophilus. Biotechnol Bioeng 2007, 98:872-881.

34. Loghavi L, Sastry SK, Yousef AE: Effect of moderate electric field frequency on growth kinetics and metabolic activity of Lactobacillus acidophilus. Biotechnol Prog 2008, 24:148-153.

35. Loghavi L, Sastry SK, Yousef AE: Effect of moderate electric

- field frequency and growth stage on the cell membrane permeability of Lactobacillus acidophilus. Biotechnol Prog 2009, 25:85-94.

The results of this research provide the first evidence that cell membrane permeabilization occurs under the presence of electric fields under MEF.

36. Serrazanetti DI, Guerzoni ME, Corsetti A, Vogel R: Metabolic impact and potential exploitation of the stress reactions in lactobacilli. Food Microbiol 2009, 26:700-711.

37. Cappato LP, Ferreira MVS, Pires RP, Cavalcanti RN, Bissagio RC Freitas MQ, Silva MC, Cruz AG: Whey acerola-flavoured drink submitted Ohmic Heating processing: is there an optimal combination of the operational parameters? Food Chem 2018, 245:22-28.

38. Pereira RN, Rodrigues RM, Ramos ÓL, Malcata FX, Teixeira JA,

- Vicente AA: Production of whey protein-based aggregates under ohmic heating. Food Bioprocess Tech 2016, 9:576-587.

The results obtained demonstrated that $\mathrm{OH}$ technology can be used to tailor denaturation and aggregation behavior of whey proteins due to the presence of a constant electric field.

39. Pereira RN, Souza BW, Cerqueira MA, Teixeira JA, Vicente AA: Effects of electric fields on protein unfolding and aggregation: influence on edible films formation. Biomacromolecules 2010, 11:2912-2918

40. Brandelli A, Daroit DJ, Corrêa APF: Whey as a source of peptides

-. with remarkable biological activities. Food Res Int 2015, 73:149-161.

This paper describes the importance of bioactivity of peptides derived from whey proteins, showing that whey constitutes an important source of bioactive peptides.

41. Ramos OL, Pereira RN, Rodrigues R, Teixeira JA, Vicente AA, Malcata FX: Physical effects upon whey protein aggregation for nano-coating production. Food Res Int 2014, 66:344-355.

42. Yu YJ, Amorim M, Marques C, Calhau C, Pintado M: Effects of whey peptide extract on the growth of probiotics and gut microbiota. J Funct Food 2016, 21:507-516.

43. Akalin A, Gönç $S$, Ünal G, Fenderya S: Effects of fructooligosaccharide and whey protein concentrate on the viability of starter culture in reduced fat probiotic yogurt during storage. J Food Sci 2007, 72:M222-M227.

44. Pereira RN, Teixeira JA, Vicente AA: Exploring the denaturation of whey proteins upon application of moderate electric fields: a kinetic and thermodynamic study. J Agric Food Chem 2011, 59:11589-11597. 
45. Rodrigues RM, Martins AJ, Ramos OL, Malcata FX, Teixeira JA, Vicente AA, Pereira RN: Influence of moderate electric fields on gelation of whey protein isolate. Food Hydrocolloid 2015, 43:329-339.

46. Ramos OL, Pereira RN, Martins A, Rodrigues R, Fuciños C, Teixeira JA, Pastrana L, Malcata FX, Vicente AA: Design of whey protein nanostructures for incorporation and release of nutraceutical compounds in food. Crit Rev Food Sci 2017, 57:1377-1393.

47. De Figueiredo Furtado G, Pereira RNC, Vicente AA, Cunha RL: Cold gel-like emulsions of lactoferrin subjected to ohmic heating. Food Res Int 2018, 103:371-379.
48. Pereira RN, Rodrigues RM, Altinok E, Ramos OL, Xavier Malcata F, Maresca P, Ferrari G, Teixeira JA, Vicente AA: Development of iron-rich whey protein hydrogels following application of ohmic heating - effects of moderate electric fields. Food Res Int 2017, 99:435-443.

49. Verhoeckx KCM, Vissers YM, Baumert JL, Faludi R, Feys M, Flanagan S, Herouet-Guicheney C, Holzhauser T, Shimojo R, van der Bolt N, Wichers H, Kimber I: Food processing and allergenicity. Food Chem Toxicol 2015, 80:223-240.

50. Tola YB, Rattan NS, Ramaswamy HS: Electrodes in ohmic heating. Ohmic Heating in Food Processing. CRC Press; 2014. 